\title{
Türk-Moğol Tarihindeki Vezirlik Kurumunun IIlhanlı Hanedanlığındaki Uygulamaları Çerçevesinde Yeniden Düşünmek
}

\section{Nilgün Dalkesen*}

\section{Öz}

Türk-Moğol tarihinde hanlar ve beyler hep mücadele içinde olmuşlar ve hanlar beylere karşı otoritelerini korumaya çalışmışlardır. Türk-Moğol devlet adamları İslam medeniyet dairesi içine girdikten sonra, bu medeniyetin sunduğu merkezi bürokratik siyasi anlayışını, ülkelerini daha iyi yönetebilmek ve hükümdarın güç ve otoritesini arttırmak için büyük bir hevesle kabul etmişlerdir. Nizâmü'l-Mülk'ün Siyasetnâme adlı eserinde en sistematik bir şekilde vücut bulan bu yeni siyasi anlayışa göre hükümdar, başında vezirin bulunduğu bürokratlarla birlikte onların engin devlet yönetme bilgi ve tecrübelerinden yararlanarak ülkelerinin mutlak hâkimi olacaktı. Ancak vezirler, hükümdarlar onlara sözünü geçirebilecek kadar güçlü olduklarında, onların yanında hanedanlığın ve ülkenin çıkarları için çalıştılar. Merkezi otorite zayıfladığında ise kendi şahsi çıkarlarına göre hareket etmişlerdir. Dolayısı ile siyasi ve ekonomik sorunların oluşmasında ve büyümesinde çok etkili olmuşlardır. Buna rağmen tarihsel kaynaklarda ve tarih yazımında genel olarak Türk-Moğol kabileleri ve onların liderleri olan emirler siyasi ve ekonomik çıkar peşinden koştukları için görev ve yetkilerini kötüye kullanan, her fırsatta hükümdara muhalif olan kişiler olarak tasvir edilmişlerdir. Bu çalışmada "Tarihte ehl-i kalem ve ehl-i kılı̧̧ zümreleri neden iki zıt kutup gibi gösterilmişlerdir? Bunun sebepleri nelerdir? sorularına ilhanlı İmparatorluğu'nda vezir ve bürokratların İran ve Anadolu'da yapmış oldukları siyasi ve ekonomik faaliyetler çerçevesinde cevap aranmaya çalışılacaktır.

Anahtar Kelimeler: Vezirlik, Illhanlı, Türk ve Moğol Devletlerinde Bürokrasi, Ehl-i Kalem, Ehl-i Seyf

\section{Reappraisal the Viziership Institution in the Turkish-Mongolian History Within the framework ofthe Applications of Ilkhanid Dynasty}

\section{Abstract}

Through Turco-Mongol history, rulers and tribal leaders (amirs) were always in a power struggle and these leaders tried to keep their authority

\footnotetext{
* Dr. Öğr. Üyesi, İstanbul Medeniyet Üniversitesi, Edebiyat Fakültesi, Tarih Bölümü, dalkesen2014@gmail.com. (Makale Gönderim Tarihi: 14.03.2018; Makale Kabul Tarihi: 13.04.2018) (ORCID ID: 0000-0002-3354-2573).
}

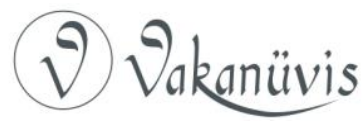


against them. Therefore, they eagerly accepted centralized bureaucratic political system in order to rule their country better and empower the ruler's authority. According to this political system which was formulated in Nizâm al-Mûlk's book Siyâsatnâmeh rulers would rule with a team of bureaucrats headed by a vizier and benefited from their experience and became the absolute leader of their country. In reality, the viziers served the benefits and well-being of the country if the ruler was powerful enough to exercise his authority. When the central authority was weak they acted according their personal interests. Hence they became effective in the formation of social, political and economic problems. On the other hand, in the historical sources and historiography Turco-Mongol tribes and their leaders were generally portrayed as being in pursuit of political and economic advantages therefore they were corrupt and they dissented the ruler. Why did the men of pen (ehl-i kalem) and the men of sword (ehl-i Kiliç) were presented as two opposite poles? This study is an attempt to find an answer this question in the framework of the political and economic activities of the Ilkhan's men of pen in Iran and in Anatolia.

Keywords: Viziership, Ilkhans, Bureaucracy in the Turco-Mongol States, Men of Pen (Ehl-i Kalem), Men of sword (Ehl-i Seyf)

\section{Giriş}

1243 Kösedağ Savaşının ardından Anadolu Selçuklu Devleti, ilhanlı hâkimiyeti altında varlığını sürdürmeye devam etti. Selçuklu Devleti'nin vezirleri, makamlarını Selçuklu idari sistemi içinde ilhanlı Devleti'nin temsilcileri olarak hizmet etmeleri şartı ile elde etmiş ve koruyabilmişlerdir. Ancak bu vezir ve üst düzey bürokratların hem Selçuklu veziri olarak Illhanlı'ya hizmet etmeleri hem de Moğol işgali ile ortaya çıkan toplumsal kutuplaşma, onların çok fazla görev ve sorumluluk almasına sebep oldu. Anadolu'nun özerk yapısından ve merkez tarafından sıkı denetlenmemesinin avantajlarını da kullanarak kendi siyasi ve ekonomik çıkarları için çalıştılar. İlhanlı hanedanlığının Selçuklu yönetimindeki temsilcisi olan Vezir Müineddîn Pervâne'nin 1277 yılında İlhanlı'ya karşı yapılan savaşta Memluklu Sultanı ile gizli bir anlaşma yaptığının anlaşılıp idam edilmesinden sonra Anadolu idari ve askeri açıdan illhanlı merkezi tarafından daha yakından takip edilmeye başlandı. 1308 yılında ise Selçuklu saltanatı tamamen ortadan kaldırılıp, Anadolu ilhanlı topraklarına ilhak edildi ancak vezirler siyasi ve toplumsal çekişmelerin tarafları olmaya devam ettiler.

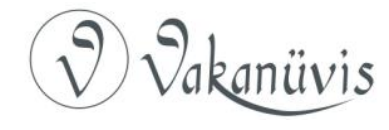


İran'da ise başlıca mali konulardan sorumlu olan İlhanlı vezirleri, hükümdarların ve emirlerin gözetimi altında olmalarına rağmen ülkenin bütçesini aşan servetlere sahip olmuşlardır. Bu denli büyük bir servet beraberinde çok büyük siyasi güç sahibi olmak demekti. Bu da siyasi ve ekonomik güç peşinde koşan ehl-i seyf sınıfını oluşturan TürkMoğol askeri aristokrasisi ile zaman zaman ortak çıkarlar söz konusu olduğunda ittifak kurmak, çıkarlar çatıştığında ise düşman olmak anlamına geliyordu. Dolayısı ile ehl-i kalem sınıfının ehl-i seyf sınıfı ile olan ilişkilerinin çerçevesini kamusal çıkarlar değil, şahsi çıkarlar çiziyordu. Başka bir ifade ile Illhanlı döneminde vezirler, merkezden uzakta veya merkezin denetiminde olmaları fark etmeksizin ehl-i seyf sınıfının başını çektiği adem-i merkezi siyasi eğilimlerin çoğunlukla karşısında değil yanında yer aldılar.

Ancak, tarihi kaynaklarda ve çalışmalarda, genellikle Türk-Moğol askeri elitinin yani ehl-i seyf'in İlhanlı'ya karşı giriştiği askeri hareketler ve isyanlardan ayrıntılı olarak bahsedilerek bozgunculuğun ve karmaşanın en önemli sebebi olarak gösterilmiştir. Bu mücadelelerin içinde yer alan ve hatta ortaya çıkan siyasi, ekonomik ve toplumsal sorunlarda büyük payları olan ehl-i kalem sınıfı bunun dışında gösterilmiş veya öyle bir algı oluşturulmuştur.

Tarihsel ve araştırma eserlerde vezirler genel olarak merkezi otoritenin yanında düzen ve nizamın temsilcisi olarak dikte edildiler. Hatta literatürde genel olarak Türk ve Moğol yöneticileri çok iyi bilmedikleri devleti idare etme işini çoğunluğu Fars kökenli vezir ve bürokratlara bıraktıkları görüşü hâkim oldu. Tarihsel çalışmalarda isyan ve itaatsizlik hep Türk-Moğol bey ve emirleri ile özdeşleştirilmiş onların tekelinde olan bir askeri-siyasi faaliyet olarak görülmüştür. Özellikle Anadolu'da İlhanlı hâkimiyeti sırasında ortaya çıkan bu tablo literatüre hâkim olan hükümdarın yanında kanun ve nizamı sağlayan vezir tanımına tamamen aykırı düşmektedir. Bu olaylar sadece illhanlı hâkimiyeti sırasında Anadolu'da meydana gelen sıra dışı bir durum muydu? Yoksa Türk-Moğol devletlerinde çoğunluğu İranlı olan ehl-i kalem sınıfının siyasi, ekonomik ve sosyal rol ve görevlerine farklı bir açıdan mı bakmak gerekmektedir? Bu sınıfın bu denli idealize edilmesinin sebepleri nelerdir? Bu makalede tarihteki ehl-i kalem ve ehl-i seyf ikilemi konusunda illhanlı örneğinden yola çıkarak farklı bir

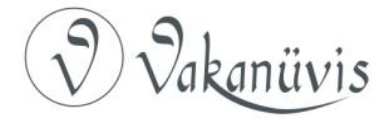


bakış açısı ortaya konulmaya çalışılacaktır. Öncesinde ise İslamiyet ile birlikte Türk-Moğol devlet sistemine bürokrasi geleneğinin yerleşmesinin sebeplerine kısaca değinilecektir. Daha sonra ise İlhanlı merkezinde ve illhanlı hâkimiyeti altındaki Anadolu'da Alaâddîn Atâ Melik Cûveynî, Reşîdüddîn Fazlullâh Hemedanî ve Müineddîn Pervâne gibi belli başlı vezirlerin kariyerleri göz önünde bulundurularak neden "ideal vezirliğin" hayata geçirilmediğini ve bunun tarih yazınına neden farklı yansıtıldığı üzerinde durulacaktır.

\section{Illk Müslüman Türkler için Bürokrasi}

Türkler Müslüman olduktan sonra devlet yönetiminde bürokrasiyi daha etkin ve yaygın kullanma isteği ve çabası içine girmişlerdir. Bunda şüphesiz üzerinde hâkimiyet kurdukları yeni bölgeleri adil bir şekilde yönetip, vergileri düzenli bir şekilde toplayabilmek amacıyla o bölgelerin yerel yönetici ve idarecileri ile işbirliği yapmaları çok önemli etken olmuştur. ${ }^{1}$ Bazı sosyal bilimciler ise göçebe Türk-Moğol yöneticiler kendilerinden çok daha üstün bir kültür ve medeniyet seviyesinde olan yerleşik İslam toplumu üzerinde hâkimiyet kurduktan sonra hızla asimile olmaları sonucu İran-isslam sentezi ile şekillendirilmiş olan bürokratik devlet sistemini benimsemediklerini ileri sürmüşlerdir. Bu durumu da "feth edenlerin fethedilenler tarafından fethedilmesi" olarak adlandırmışlardır. ${ }^{2}$ Büyük Selçuklu Devleti'nin veziri Nizâmü'l-Mülk'ün (1018-1092) yazdığı Siyâsetnâme adlı eseri ise bu konuda adeta sembol olmuştur. Selçuklu Sultanı Melikşah'ın 1077-1078'de emrindeki devlet adamlarına, devlet idaresine dair kitap yazmasını emretmesi üzerine yazdığı Siyasetname adlı eserinde, Nizâmü'l-Mülk Orta Asya Türk devlet geleneğinden farklı İran-i̇slam sentezi olarak isimlendirilen, hükümdarın ve bürokratların sultan ile beraber kural ve kaidelere göre yönettikleri merkeziyetçi bir yönetim anlayışı ortaya koymuştur. Ayrıca, Nizâmü'l-Mülk ülkenin

\footnotetext{
${ }^{1}$ Danuu, Ankhbayar, IIhanlı Devleti'nde Vezaret, Yayınlanmamış Doktora Tezi, Ankara 2016, s. 17-18.

2 Beatrice Forbes Manz, "Reflections on Nomads, Agriculture and Urban Life", Horizons of the World: Festschrift for İsenbike Togan (Hudûdü'l-Âlem: İsenbike Togan'a Armağan), ed. İlker Evrim Binbaş\&Nurten Kılıç-Schubel, İstanbul, 2011, s. 335.
}

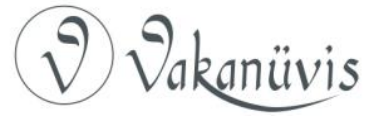


çeşitli şehirlerinde kendi adı ile inşa ettirdiği Nizâmiye medreseleri aracılığı bu fikirlerin kurumsallaşıp kalıcı olmasını sağlamıştır. ${ }^{3}$

Ancak Nizâmü'l-Mülk'ün Siyasetnâme adlı eseri yazılmadan sekiz yıl önce, Karahanlı Yusuf Has Hacib (ö.1070) Doğu Karahanlı hükümdarı Tamgaç Uluğ Buğra Han'ın himayesinde Türk-İslam edebiyatının en eski eseri olan Kutatgu Bilig'i (1069-1070) yazmıştır. Bu İran-İslam bürokratik devlet anlayışını İ̧ Asya bağlamında kavramsallaştıran ilk eserdir. ${ }^{4}$ Ayrıca nasihatnâme edebiyatının önemli eserleri olan Kabusnâme ve Siyasetnâme'nin öncüsüdür. ${ }^{5}$ Böylesine öncü niteliğinde bir eserin İslam kültür ve medeniyetini çok iyi bilen bir Türk tarafından (Yusuf Has Hacib) ve Orta Asya'da hüküm süren (Doğu Karahanlı Devleti'nin toprakları Kaşgar, Fergana ve Balkaş Gölü civarı) bir hükümdara atfedilmesi çok anlamlıdır. Böyle bir eserin Orta Asya'da yazılması, Türk ve Moğolların vezaret sistemine bu denli önem vermelerinin sebebinin, sadece yerleşik toplumları yönetme ihtiyacından veya sadece hâkimiyet kurdukları İran ve Orta Doğu'da İran-İslam kültürünün etkisi altında kalarak asimile olmalarından kaynaklanmadığını göstermektedir. Başka bir ifade ile bu olayın sadece dış dinamiklerin etkisi ile gerçekleşmediğini, Türk ve Moğol toplumlarının kendi iç dinamiklerinin de merkezi-bürokratik bir yönetim anlayışına ihtiyaç duyduğunu göstermektedir. Barfield'in şu sözleri, Türk ve Moğolların eski yönetim anlayışlarını değiştirmeye, hükümdarın güç ve etkisini arttıran yeni bir sisteme ihtiyaç duyduklarını ve buna çok hevesli olduklarını göstermektedir:

Bu Türk ve Moğol konfederasyonları yüz binlerce insanın güçlü bir hanın otoritesi altında birleştikleri hiyerarşik politik yapılardı. Bu hanlardan bazıları büyük imparatorlukları fethederek uzun ömürlü devletler kurdular. Genel olarak, bu hanlar yerleşik

\footnotetext{
${ }^{3}$ Scott C. Levi \& Ron Sela (ed.), Islamic Central Asia: An Anthology of Historical Sources, Bloomington, 2010, s. 92; Ömer Soner Hunkan, Türk hakanlığı (Karahanlılar) (3. Baskı), İstanbul, 2011, s.18-19.

${ }^{4}$ Kutadgu Bilig mutluluğun elde edilmesi demektir. Bu maddi ve manevi, dünyevi ve uhrevi mutluluktur. Mutluluğun elde edilmesi adaleti uygulayan hükümdar Gündoğdu, mutluluğu temsil eden vezir-azam (başbakan) Aydoldu, Aydoldu'nun anlayışı temsil eden oğlu vezir Öğdülmüş ve ahreti ve akibeti temsil eden zahit bir kişi olan Öğdülmüş'ın akrabası olan Odgurmuş arasında geçen diyaloglarda işlenir. Yusuf Has Hacip, Kutadgu Bilig, Haz. Yaşar Çağbayır, (8. Baskı), Ankara, 2011, s.XVIII-XIX.

${ }^{5}$ Scott \& Sela, a.g.e., s.76.
}

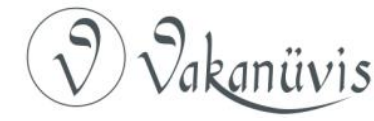


hükümetleri yönetme konusunda çok az bir deneyime sahiptiler. Fakat yerli danışmanların önerdiği merkezi yönetim anlayışına karşı oldukça hevesli idiler çünkü bu model kendi taraftarı olan kabile üyelerini kontrol altında tutmak ve aynı zamanda fethettiği halktan vergi toplamaya olanak sağlıyordu. Iran ve Bizans'ın imparatorluk geleneği iç Asya göçebelerine yabancı olmasına rağmen, hiyerarşik otoritenin kabulü ve hükümdarlığın babadan oğla geçmesi anlayışı daha öncesinden kabile konfederasyonlarının organize edilmesiyle kendi kültürlerine yansımış ve köklü bir şekilde benimsenmişti. ${ }^{6}$

Benzer bir siyasi yapıya sahip olan İlhanlı'daki siyasi, idari ve ekonomik sorunları ortadan kaldırmak için pek çok reformlar yapan Gazan Han'ın bu reformlarının esas amacı da ülkeye merkezi otoriteyi hakim kılmak idi. ${ }^{7}$ Örneğin Gazan Han vefatından beş yıl önce kardeşi Olcaytu'yu veliaht tayin ederek ilk resmi veliaht tayinini gerçekleştirmiş ve böylece biat ve veraset fermanı gibi Yakındoğu coğrafyasındaki yerleşik ananelerin kullanımını resmileştirilmiştir. ${ }^{8}$

Moğollar Cengiz Han döneminden itibaren bürokratik yapılanmalarını çok bilinçli bir şekilde planladılar. Onlar yer ve zamana göre Çinli ve İranlı bürokratları, Moğolistan'ı yöneten Türk-Moğol ve Kuzey Çin'i yöneten Kitanlıların deneyimlerini kullanarak oluşturduğu "karma" bir idari sistem kurdular ve bu sistem Aigle'ye göre onların başarısının esas sebebi olmuştur. ${ }^{9}$ Sasani ve Abbasi İmparatorlukları

\footnotetext{
${ }^{6}$ Thomas J. Barfield, "Tribe and State Relations: Inner Asian perspective," Tribes and State Formation in the Middle East Ed. Philip S. Khoury and Joseph Kostiner, Univ. of California Press, 1990, s.159. Konfederatif Türk -Moğol devlet yapısı ile ilgili Z. V. Togan "Türk ve Moğol illerinde memleket ülüş (ulus) ler sıfatıyla hükümdar efradı arasında, kopı (devlet hizmetinde bulunan yüksek askerlere, büyük başarılar karşılığı ve mükafat olarak emlak ve arazi temliki yapılması) larda yine evlada taksim edilince 4-6 batında (yaklaşık 100-150 yıl) yurtlar küçülür ve bu yıkılır" ifadesi ile Türk ve Moğollarda ülüş sisteminin siyasi ve maddi gücün paylaşımın uzun ömürlü ve merkezi otoritenin oluşumuna imkan vermediğini kısa ve net bir şekilde ortay koymaktadır. Daha ayrıntılı bilgi için bkz. Zeki Velidi Togan, Umumi Türk Tarihine Giriş, İstanbul, 1970, 296.

${ }^{7}$ Osman Gazi Özgüdenli, Gâzân Han ve Reformları, İstanbul, 2009, s.113.

${ }^{8}$ Özgüdenli, a.g.e., s.246.

${ }^{9}$ Denis Aigle, "Iran under the Mongol Domination: The Effectiveness and failings of a Dual Administrative System", Le Pouvoir À lâge Dessultanats Dans Le "Bilād alShām/Power in the Age of Sultanates in the "Bilād al-Shām" Institut Francais du Proche-Orient 2006-2007, s. 67-68.
}

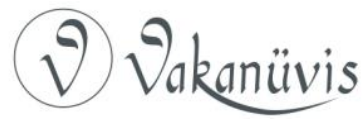


üzerine kurulan illhanlı Devleti, bölgenin devlet yönetme kültürünü ve tarihini iyi bilen zümreleri (ehl-i kalem) devletin idari ve mali işlerini yürütmek üzere görevlendirmiştir. Hükümdar ise Moğol askeri aristokrasisi (ehl-i Kılıç) ve yerli aristokrasi (ehl-i kalem) zümreler üzerinde hakem rolü oynamıştır. ${ }^{10}$ Moğollar idari çıkar sistemin yarısını yerli yarısını da Moğollardan, en azından yerli olmayan kişilerden oluşturarak ikili bir sistem kurdular. ${ }^{11}$

Moğollar bu karma idare sistemini oluştururken, İmparatorluğun idari yapısını merkezin denetimi altında tutmaya çok önem vermişlerdir. Daha en başından merkezde bir yazmanlık ve Çin, Türkistan ve İran'da bu kurumun bölgesel şubeleri açılmıştır. ${ }^{12}$ İran'da bu görevi Argun Ağa 1243 yılına kadar devam ettirmiştir. Argun Ağa İran ve Horasan'ın valisi olarak aralarında önemli sayıda yerli halktan insanları da dâhil ederek oluşturduğu kadrosu ile vergileri belirlemiş ve toplamıştır. ${ }^{13}$ Ayrıca, Moğollar haraç aldıkları devletlerin üzerinde, Büyük Han'ın temsilcisi olarak görev yapan Daruğaçi aracılığı ile idari denetimi sağlıyorlardı. Bunların hepsi Moğol veya Türk idi ve otoritelerini güçlendirmek için komuta ettikleri bir askeri birlikleri de vardı. Onlar vergileri ve haraçları toplama, posta servisini (yam teşkilatı), toplumsal uzlaşıyı sağlama ve barışı korumakla görevli idiler. Ayrıca Darugaçiler, yerel hanedanlıklarda hizmet veren çalışanları da denetlemekteydiler. ${ }^{14}$

Ilhanlılar'ın ehl-i kalem sınıfı ile bu denli yakın işbirliği içinde olmalarının sebebi aynı zamanda hükümdarlar ile gücü paylaşmayı kendi doğal hakları olarak gören beyleri dizginlemek istemelerinden kaynaklanmaktaydı. Örneğin Cûveynî̀nin idam edilmesinden sonra Argun Han Moğol Emirlerinden Emir Buka'yı vezir yapmış, emir olduğu için emrinde bir ordusu da olan Emir Buka, kardeşleri ile birlikte nerde ise ülkeyi ele geçirecek derecede güçlenince, Argun Ağa Emir Buka'yı

10 IIlhan Erdem, Erdem, İlhan, “Olcaytu Han'ın Ölümüne kadar İlhanlılar'da Yaşanan Siyasal-Kültürel Gelişmeler ve Yakın-Doğu'ya Etkileri”, (ayrı basım), AÜDTCFTAD, 31 (2000), s. 9.

${ }^{11}$ Aigle, a.g.m., s. 72.

${ }^{12}$ Aigle, a.g.m., s. 70.

${ }^{13}$ Aigle, a.g.m., s.71; Bertold Spuler, Iran Moğolları; Siyaset, Idare ve Kültür, ihanlılar Devri, 1220-1350, Çev. Cemal Kprülü, Ankara 1957, s.303-333.

${ }^{14}$ Aigle, a.g.m., s. 71.

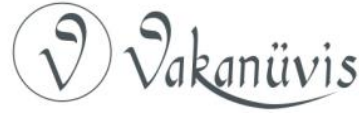


idam ettirip yerine Reşîdüddîn'i vezir yapmıştır. ${ }^{15}$ Yine benzer bir örnekte, devletin idari işlerini yürüten Emir Nevrûz'un çok güçlenmesi üzerine Gazan Han onu idam ettirmiş ve Illhanlı hanları bir daha asla bir Moğol emirini vezirlik görevine getirmemişlerdir. ${ }^{16}$

Ayrıca, merkezde ehl-i kalem sınıfı, ehl-i kılıç sınıfından sonra gelmekteydi ve sekreteri (bitikçi), vergi toplayıcısı (darugacı) ve hâkimleri ile Moğol yönetimi bütün kademelerdeki İranlı idarecilerin işlerine karışıyorlardı. İlhanlı döneminde vezirin becerisi özellikle devletin maliyesi ile sınırlı idi. ${ }^{17}$ Sarayda vezirler yalnızca emirlerin onları hükümdara takdim etmesi ile onun huzuruna çıkabilirlerdi. ${ }^{18}$ Örneğin Olcaytu Han'ın son yıllarında Tâcüddîn Alişah Gîlânînnin nüfuzu çok artmıştı ve Emirü'l-ümerâ'nın izni olmadan doğrudan Olcaytu ile görüşmeye başlaması üzerine Emir Çoban'ın “Ey! yazıklar olsun Hülagu ve Abaka dönemine. Birisi padişaha bir sözünü arz edecek olursa önceden tüm ümera ile istişare etmeden bunu yapamazdı. Fakat şimdi durum o raddeye geldi ki, Tacik, emirlerle istişare etmeden gece yarılarında padişah ile yalnız kalıp istişarede bulunuyor ve ümeranın reyini boşa çıkarıyor! Hace, Emiri susturdu ve onun konuşan diline ket vurdu!" diye serzenişte bulunması bu konuya güzel bir örnek teşkil etmektedir. ${ }^{19}$ Böylece, Moğol emirler nüfuz ve itibarını başarıyla korumaktaydılar. Bu yüzden de çoğu zaman vezirlerden daha etkili oluyorlardı. Hükümet fermanlarında illhan isminden sonra ulus emirleri adı, daha sonra vezir/ Sâhib-i Divân adı anılırdı. ${ }^{20}$ Ayrıca vezirlerin birbirlerini denetlemesi için maliye işlerine bakan vezir diğer vezirden ayrılır ve onun yardımcısı olarak görev yapardı. Bir belgeye iki vezir aynı anda imza atardı. ${ }^{21}$

$\mathrm{Bu}$ denetim mekanizmaları vergilerin adil bir şekilde toplanıp merkeze gönderilmesini sağlayamadı, siyasi ve idari istikrarsızlıkların önüne geçemedi. Bunun en önemli sebebi İlhanlılar'ın merkeziyetçi

\footnotetext{
${ }^{15}$ Danuu, a.g.e., s.178-179.

${ }^{16}$ Aigle, a.g.m., s.74.

${ }^{17}$ Aigle, a.g.m., s. 72.

${ }^{18}$ Aigle, a.g.m., s. 73.

${ }^{19}$ Âbû'I-Kâsim Abdullah bin Muhammed el-Kâşânî, Târîh-i Olcâytû, Tahran 1348, s.195196.

${ }^{20}$ Danuu, a.g.e., s.338-339.

${ }^{21}$ Aigle, a.g.m., s. 73.
}

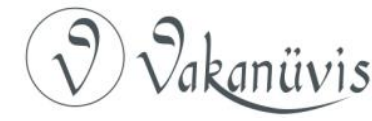


devlet anlayışını savunan İran-i̇slam devlet anlayışını var olan adem-i merkezi devlet yapısını değiştirmeden ona eklemlemeleri olduğu söylenebilir. Bu sistem zümrelerin birbirlerini denetlemesi üzerine kurulmuştu. Hükümdar her iki zümreyi, her iki zümre birbirini aynı zamanda zümreler kendi içlerinde de birbirlerini denetliyorlardı. ${ }^{22}$ Melville'e göre bu ikili hantal yapı sürekli bölücülük yapmakta idi. ${ }^{23}$ Ancak "ortak çıkarlar" her iki zümrenin kendi aralarında ve kendi içlerinde dost veya düşman olmasına sebep olmuştur.

Öncelikle, yerli bir bürokrat için vezirlik veya üst düzey bir makama gelme yolları bu denetleme mekanizmasını işlevsiz hale getirdi. Bir vezirin Moğol devlet adamları ile olan iyi ilişkileri onun vezirlik makamını elde etmesini ve korumasını sağlıyordu. Noyanın naibi olmak siyasi kariyerin başlangıcı demekti. Bu iyi ilişkiler çoğunlukla ortak çıkarlar üzerine kuruluyordu. ${ }^{24}$ Ehl-i kalem sınıfına mensup kişiler bölgenin zengin ve köklü ailelerine mensup idiler ve sahip oldukları makamları kendi evlatlarına ve aile bireylerine miras bırakma geleneğini benimsemişlerdi. Bir bakıma bu coğrafyanın fatihleri değişmiş ama bürokratları değişmemişti; şah kim olursa olsun, yeni kurulacak siyasi yapının idaresinde görev almayı kendilerinin tarihsel hakları olarak görüyorlardı. Örneğin, bu yerli İranlı aristokrat aileler, Moğol yönetiminde bir makamı garantilemek için daha Hülegü İran'a gelmeden önce, Moğol askerlerinin ihtiyaçlarını karşılamışlardı. Hatta bu büyük aileler Büyük Han Ögedey ile bağlantı kurmak için Moğolistan'a gitmişlerdi. Selçuklular ve Harzemşahlar zamanında yüksek makamlarda olan bir ailenin oğlu olan Ata Melik Cûveynî, iki defa Moğolistan'a gitti ve bir süre orada kaldı. Argun Ağa Horasan'a

\footnotetext{
${ }^{22}$ Ilhanlılar devlet sistemi içinde çok büyük siyasi, ekonomik ve askeri güce ulaşan bir emiri ortadan kaldırmak için çoğunlukla doğrudan bir müdahalede bulunmalarına gerek kalmıyordu. Çünkü bu kişiyi kendileri için tehdit olarak gören diğer emirler aralarında organize olup siyasi entrikalar ve askeri müdahaleler ile o kişinin ve ailesinin varlığına son verebiliyorlardı. IIlhanlı hanları ise Gazan Han'ın Emir Nevruz'un ortadan kaldırılması olayında olduğu gibi görmezden gelebiliyorlardı Melville, Charles, "Abû Saî'd and the Revolt of the Amirs in 1319", L'Iran Face A La Domination Mongole, Ed. By Denis Aigle, Téhéran 1997, s. 89-117.

${ }^{23}$ Melville, Charles, "Anatolia under the Mongols", The Cambridge History of Turkey, Vol I, Byzantium to Turkey 1071-1453, yay. Kate Fleet, Cambridge University Press 2009, s. 99

${ }^{24}$ Aigle, a.g.m., s. 73-74.
}

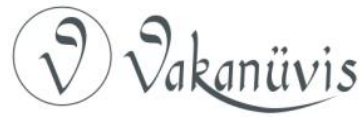


vali olarak atandığında Atâ Melik Cûveynî ve geleceğin baş veziri (Sâhib-i Divân) Şems al-Dîn Muhammed'i kendisine yardımcı olarak seçmesi kaçınılmazdı. ${ }^{25}$ Vezir Müineddîn Süleyman (emîr-i hâcib) Nizâm el-Dîn Hûrşîd Pervâne ile birlikte Sultana danışmadan Baycu Noyan'ın arkasından Muğan'a giderek, orada ağır vergiler ve hediyeler karşılığında barış yaptılar ve sahip oldukları makamlarını korudular. ${ }^{26}$ Ayrıca vezirler siyasi görevleri ile birlikte kendi şahsi işlerini birlikte yürütmüşlerdir. Örneğin Abaka tarafından Anadolu'nun mali ve idari sitemini düzenlemek için görevlendirilen Cûveynî, Sivas'ta 1271 tarihinde çifte minareli medreseyi yaptırmıştır. Melville'e göre kitabede ne Abaka Han'ın ne de Selçuklu Sultanın adı zikredilmektedir. $\mathrm{Bu}$ da bu yapının Cûveynî'nin kendi kişisel girişimi olduğunu ve muhtemelen bu önemli şehirde kendi şahsi çıkarlarını geliştirmek için bu eseri yaptırmıştır. ${ }^{27}$

Servet sahibi olmak onlar için sadece şahsi bir heves değildi. Servetleri onların makam ve mevkiler elde etmelerinin ve bunları elde tutmanın hatta yeri geldiğinde canlarını korumalarını sağlamıştır. ${ }^{28}$ Aigle'ye göre İlhanlı döneminde yerel memurlardan en üst düzey divan üyelerine kadar her seviyeden ilişkide acımasızlık hâkimdi. Her türlü makamın satılık olduğu bir düzende büyük bir servete sahip olmak

\footnotetext{
${ }^{25}$ Aigle, a.g.m., s. 71.

${ }^{26}$ Aksaraylı Mehmed Oğlu Keriüddin Mahmud, Müsâmeret ül-Ahbâr; Moğollar Zamanında Türkiye Selçukluları Tarihi, Mukaddime ve Haşiyelerle Tashih ve Neşreden Osman Turan, Ankara 1944 s.42 ; Mahmûd bin Muhammed Aksarayî, MüsâmeretülAhbâr ve Müsâyeretü'l Ahyâr, Çev. Mürsel Öztürk, Ankara 2000, s.33. Reşiddeddîn ise Hülagü'nün Rum'un yönetiminin Mu'î el-Dîn Pervâne'ye verdiğini ileri sürmekte ve Nizâm el-Dîn Hûrşîd adlı birinden bahsetmemektedir. Rashîd el-Dîn Fazlullâh, Câmi'elTevârîh, ed. Behmen Kerîmî, Tahran 1387, s.734. Faruk Sümer Kösedağ yenilgisinden sonra Vezir Müineddîn Pervâne'nin babası Sâhip Mühezzibüddîn Ali, Sultana anışmadan Baycu Noyan'ın arkasından Muğan'a gitmiş, orada vergi karşılığında barış yapmış. Bkz. Sümer, a.g. m., s. 10.

${ }^{27}$ Melville, a.g.m., s.72.

${ }^{28}$ Anonim Selçukname'de Pervâne'nin Memluklu Sultanı Melik Zahir'e yolladığı mektuplar ve Moğollara ihaneti ortaya çıkınca Pervâne'ye büyük sevgi besleyen İlhanlı Han'ı Abaga onu öldürmeye karar vermiştir. Sâhib Fahreddin Ali "Kendini mal ile kurtar!" diye tavsiyede bulunduğunda Pervâne de "Ben bu hayattan bıktım!" der ve kendisinin affedilmesi için hiç bir çaba göstermez. Tarîh-i Âl-i Selçuk; Anonim Selçuknâme, s.49.
}

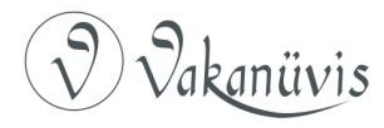


mutlaka gerekliydi. ${ }^{29}$ Vezir Şemseddîn Cûveynî ilhanlı şehirlerini mamur etmek ve yeni yerleşim yerleri kurmak için, Moğol aristokrat tarafından "incü" olarak ilan edilen İran'ın başlıca büyük şehirleri ve köyleri satın alıp imar ve maliyeden mütehassıs olan bürokratları ataması ile İlhanlı devleti içindeki kendi ağılığını gittikçe hissettirmeye başlamıştı. 1280 yılında Şemseddin Cûveynî tarafından satın alınan arazı 4 bin tümen değerinde olup dönemin bir köyü 10 bin dinara satıldığından hesaplamak gerekirse toplam 4 bin köy ve kasabaya tekabül etmektedir. ${ }^{30}$ Şemseddin Cûveynî'nin gelirinin neredeyse hükümdar hazinesi ile aynı derecede olduğu iddia edilmektedir. Anadolu'da 1277 yılında yaşanan katliam sırasında bir kaç şehrin Şemseddin Cûveynî tarafından satın alındığı da belirtilmektedir. Şemseddin Cûveynî idam edildiğinde tüm mal varlığına el konularak incü divanına nakil edildiğinde servetinin toplam tutarı 360 bin tümene ulaşmaktaydı. ${ }^{31}$ Cûveynî ailesinin bu denli güçlenmesinden rahatsız olan bazı bürokrat ve emirler Abaka döneminde itibaren Cûveynî ailesini ortadan kaldırmak için çok uğraştılar ve 16 Ekim 1284 tarihinde Argun Han zamanında Cûveynî Ebher şehri kapısında idam edilmesini sağladılar. ${ }^{32}$

Argun, Şemseddin Cûveynî́nin katlinden sonra devlet vezirliği görevini Emir Buka'ya verdi. Samimi bir Budist olan Argun Han'ın devlet işlerinden uzaklaşarak inzivaya çekilmesi ile ortaya çıkan siyasi boşluktan Vezir Emir Buka ve kardeşi Aruk faydalanmışlardır. Bu iki kardeş devletin tüm işlerine el koymuşlar ve hatta ün ve nüfuz açısından Argun ile yarışır bir hale gelmeleri üzerine, Emir Buka'yı 16 Ocak 1289 tarihinde Argun Han idam ettirmiştir. ${ }^{33}$ Böylece, devlet bürokrasindeki İran-Moğol unsur arasındaki dengenin ne kadar önemli olduğu anlaşılmıştır. IIlhanlı Devleti'ndeki Moğol unsurların ağır basması nedeniyle taht mücadelesinin devleti felakete götüreceğinin farkına varan Argun Han, vezir Şemseddin Cûveynî'den sonra bozulan İran-Moğol unsurlar arasındaki dengeyi yeniden tesis etmeye

\footnotetext{
${ }^{29}$ Aigle, a.g.m., s. 76.

${ }^{30}$ Danuu, a.g.e., s. 152.

${ }^{31}$ Danuu, a.g.e., s. 349.

${ }^{32}$ Danuu, a.g.e., s. 166-170.

${ }^{33}$ Danuu, a.g.e., s. 171-179.
}

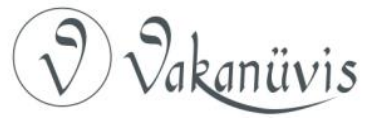


çalışmıştır. Bu dönemde Hâce Reşîdüddîn Fazlullah Hemedanî vezir olmuştur. ${ }^{34}$

İlhanlı vezirleri içinde en zengin olan Reşîuüddîn Fazlullâh Hemedanî idi. Reşîuüddîn'in mektuplarına göre, "özel toprağı" olarak adlandırılan mülkleri, ilhanlı Devleti'nin birçok bölgesinde bulunmaktaydı. Bunlar, Bam ve Habis bölgesinde (Kirman vilayeti), Basra bölgesinde, Avasime'de, Musul bölgesinde (Dicle nehrinin başında) ve Ahvaz'da idi. Hayattayken mülk edindiği toprak ölçüsü toplam olarak 12770 feddana ulaşmaktadır. Bir aile üyesinin 4-5 kişiden oluştuğunu göz önünde bulundurulunca Reşîuüddîn'in mülkünde yaklaşık 170 bin çiftçinin çalıştığı tahmin edilmektedir. ${ }^{35} \mathrm{Bu}$ denli büyük ekonomik gücün yanı sıra, Reşîuüddîn ailesi devletin idari yapısını denetimleri altına almışlardı. O, 14 oğlundan 10'unu 10 farklı bölgeye yönetici olarak atadı. Ayrıca pek çok vilayetin valisi de Reşîdüddîn'in akrabaları ya da onun güvenilir hizmetkârları idi. ${ }^{36} \mathrm{Bu}$ denli güçlenmek düşman kazanmak demekti. Öncelikle onun yardımcısı olan Vezir Tâcüddin Alişah Gîlânî, onun Han'ın nazarındaki üstün konumunu elinden almak için çok çaba sarf etti. Gîlânî Olcaytu'nun son dönemlerinde çok güçlenerek, Reşîdüddîn'i bertaraf etme aşamasına geldi. Varlığının ve makamının tehlikede olduğunu anlayan Reşîuüddîn, kendi durumunu kurtarmak için Şehzade Ebu Sa'îd'in hazinenin açığını kapamak amacı ile istediği miktarı şahsi mülkünden karşıladı. ${ }^{37}$ Ancak Reşîdüddîn'in düşmanları vazgeçmediler. Onun şerbetdâr olan oğlu Hâce İbrahim'e talimat vererek Olcaytu Sultan'a zehir içirme suretiyle suikast düzenlediğine dair söylenti çıkararak idam edilmesini sağladılar. ${ }^{38}$ Böylesine bir rekabet ortamında, bu denli siyasi ve ekonomik güç sahibi olmak veya olmaya çalışmak sonunda bir entrikaya kurban gitmeyi kaçınılmaz kılıyordu. Nitekim İlhanlı vezirleri içinde İran'da Vezir Tâcüddin Alişah Gîlânî (öl.1318), Anadolu'da ise Sahib Fahreddin Ali (öl.1288) dışında bütün vezirler ya idam edildiler ya da öldürüldüler.

\footnotetext{
${ }^{34}$ Danuu, a.g.e., s. 180-193.

${ }^{35}$ Danuu, a.g.e., s. 353-354.

${ }^{36}$ I. Pavlovich Petrushevsky, "Rashīd al-Dīn's Conception of State", Central Asiatic Journal, 14 ,1/3 (1970), s. 159.

${ }^{37}$ Danuu, a.g.e., s. 246- 247.

${ }^{38}$ Danuu, a.g.e., s. 246
}

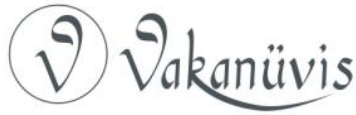


Merkezi yapıyı kurumsallaştırmadan, zümrelerin birbirini denetleme ilkesi anlayışına göre kurulmuş olan bu ikili bürokratik yapı, Anadolu'nun ilhanlı merkezi denetiminden uzak olmasından dolayı siyasi ve idari açıdan daha önemli sorunların oluşmasına sebep olmuştur.

\section{İlhanlı Döneminde Anadolu'da Vezaret}

Selçuklularda vezirliğin devletin işleyişine ve çıkarlarına zarar verecek seviyeye gelmesi 1243 Kösedağ savaşından önce, ${ }^{39}$ Selçuklunun altın çağı olarak nitelendirilen Alâeddin Keykûbad zamanında başlamıştır. Örneğin, Alâeddin Keykûbad 1237 yılında öldüğünde yerine oğlu İzzeddin Kılıç Arslan'ı veliaht olarak tayin etmesine rağmen, Atabey Şemseddîn Altunapa, Tâceddîn Pervâne, Üstâdü'd-dâr Lala Cemâleddîn Ferruh, Sadeddîn Köpek ve Gürcüoğ/u Zahîreddîn'in olduğu grup diğer oğlu Gıyaseddin Keyhüsrevi tahta çıkardılar. ${ }^{40} \mathrm{O}$ iktidara gelir gelmez Selçuklu yönetim kadrosu hızla yabancıların eline geçti. ${ }^{41}$ Bunlardan Vezir Saadeddîn Köpek Sultanı en çok etkileyen kişi olmuştur. İktidar gücü onun (Saadeddîn Köpek) elinde tam bir zülüm ve cinayet aracı haline dönüşmüştür. ${ }^{42} \mathrm{Her}$ ne kadar 1243 Kösedağ savaşı vezirlerin çok güçlenmesinde dönüm noktası olarak kabul edilse de ${ }^{43}$ Alâeddin Keykûbad'ın vasiyetinin

${ }^{39}$ Faruk Sümer, "Anadolu'da Moğollar”, Selçuklu Araştırmaları Dergisi I, 1969, TTK, Ankara 1970, s. 6-7, 9-11. Refik Turan I. Alaeddin Keykubad devrine kadar kaynaklarda vezir isminin nadiren geçtiğini ileri sürmektedir. Ayrıntılı bilgi için bkz. Refik Turan, Türkiye Selçuklularında Hükümet Mekanizması (Vezîr ve Divân), İstanbul, 1995, S.38.

40 Salim Koca, "Sultan Alâeddîn Keykubâd'dan Sonra Türkiye Selçuklu Devleti İdaresinde Ortaya Çıkan Otorite Zâfiyeti ve Emîr Sadeddîn Köpek'in Selçuklu Saltanatını Ele Geçirme Teşebbüsü," Gazi Üniversitesi Türkiyat Araştırmaları Dergisi, 7 (Güz 2010), s.71-72.

${ }^{41}$ Koca, a.g.m., s. 73; Mükremin Halil Yinanç, Türkiye Tarihi Selçuklular Devri, II. Cilt, Yayına Hazırlayan Refet Yinanç, Ankara, 2014, s.149.

${ }^{42}$ Koca, a.g.m., s. 73-79.

${ }^{43}$ Refik Turan Selçuklu vezirlerinin çok güçlenmesini Moğol hâkimiyeti ile birlikte başladığını öncesinde ise hanedanın üzerinde vezîr baskısı veya selâhiyet gaspı diye bir olay kesinlikle mevcut olmadığını ileri sürmektedir. Ayrıca yazar Selçuklu vezirlerinin tamamen Sultan'ın mutlak otoritesi altında olduğunu, hanedanın ve sultanın haklarının hudutlarını aşmak niyeti olduğu sezilen şahısların, Alâeddin Keykûbad devrinde Seyfeddin Ayaba ve II. Giyaseddin Keyhüsrev devrinde Sadeddin Köpek örneklerinde olduğu bunlar Sultan tarafından ölüm cezasına çarptırıldıklarını söylemektedir. Turan, a.g.e., s.18.

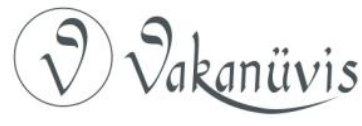


yerine getirilmemesi vezirlerin devlet içinde devlet olma süreçlerinin 1243 'ten önce başladığının bir kanıtı olarak değerlendirilebilir. Ayrıca, Kösedağ yenilgisinden sonra Vezir Müineddîn Süleyman (emîr-i hâcib) Nizâm el-Dîn Hûrşîd Pervâne ile birlikte Sultana danışmadan Baycu Noyan'ın arkasından Muğan'a giderek, orada ağır vergiler ve hediyeler karşılığında barış yaptılar. Sultan Rükneddin'i Burdur kalesinden çıkarıp Selçuklu tahtına oturttular. ${ }^{44}$ Daha sonra Nizâm el-Dîn Hûrşîd'in yerine Müineddîn Süleyman Pervâne unvanına da sahip oldu. Aksarayî Mühezzibüddîn Ali'nin oğlu Müineddîn'in cihandarlık ve sultan tayin etme sıfatının yanında pervanelik lakabına da kavuştuğunu ifade etmesi, ${ }^{45}$ o dönemde Anadolu'da vezirlik kurumunun Selçuklu Sultanlığını fiilen ele geçirdiklerini göstermektedir.

Aslında vezirlerin bu denli güçlenmesinde şüphesiz daha Moğollar Anadolu'yu ele geçirmeden önce, Moğolların önünden kaçıp gelen çok sayıda ehl-i kalem sınıfına mensup kişilerin, yerleştikleri şehirlerde kendi sosyo-kültürel çevrelerini oluşturdukları, ${ }^{46}$ devlet hizmetinde kadrolaştıkları anlaşılmaktadır. Yinanç'ın ifade ettiği gibi "artık bundan sonra (Alâeddin Keykûbad'dan sonra Gıyâseddîn Keyhüsrev tahta çıkınca) Anadolu'nun eski beylerinin oğullarına nadiren tesadüf olunacaktır. Emaretlerde, defterdarlıklarda, müsellemliklerde bilhassa kadılıklarda memleketle hiçbir vech ve suretle zerre kadar alakası olmayan İsfehanlı, Kirmanlı, Şirazlı, Tebrizli, Tiflisli, Hemedanlı, Cüveynli, Cürcanlı, Reyli, Kazvinli, Buharalı, Kaşgarlı yabancılar

\footnotetext{
${ }^{44}$ Aksarayî, a.g.e., s.42 ; Öztürk, a.g.e., s.33. Reşiddeddîn ise Hülagü’nün Rum'un yönetiminin Mu'î el-Dîn Pervâne'ye verdiğini ileri sürmekte ve Nizâm el-Dîn Hûrşîd adlı birinden bahsetmemektedir. Rashîd el-Dîn Fazlullâh, Câmi'el-Tevârîh, ed. Behmen Kerîmî, Tahran 1387, s.734.

${ }^{45}$ Aksarayî, a.g.e., s.45; Öztürk, a.g.e., s.35.

${ }^{46}$ Muinüddin Pervâne başta Mevlâna Celâleddin olmak üzere Farsça konuşup yazan mutasavvıflar ve alimler ile yakın ilişkiler kurmuştur. 0 , sarayında kendisine ziyafetler, ayinler ve sohbetler tertip etmiş ve ziyafetinde irşadlarından faydalanmıştır. Kendilerine ve müridlerine ihsanlarını eksik etmezdi. Mevlâna Celâleddin mektuplarında Muinüddân Süleymân'a "Uluğ-Pervâne, Pervâne-i Azâm, Kutluğ Uluğ Pervâne, Muinüddîn Pervâne Beğ" diye hitap etmiş ve onun ilim adamlarına, talebelere ve dervişlere yaptığı yardımlar hakkında bilgi vermiştir. Mevlevî kaynakları Muinüddîn Süleymân devri ve şahsı hakkında çok medhiyeler söylemekte ve fıkralar nakletmektedir. Turan, a.g.e., s.131.
}

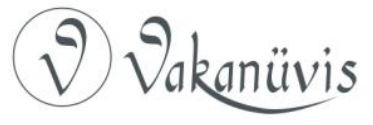


çalışmaya başlamıştır." ${ }^{47}$ Selçuklu Devleti'nde daha Moğol hakimiyeti altına girmeden önce, iş başına gelen 24 vezirden 18 'inin İran asıllı olması devlet teşkilâtı içerisinde özellikle İranlı unsur gittikçe güçlendiğini ve yönetimde söz sahibi haline gelmiş olduğunu göstermektedir. ${ }^{48}$

IIlhanlılar Selçuklu hanedanlığına resmen son vermeden, Selçuklu bürokrasisini denetimi altına alarak Anadolu üzerinde hâkimiyet kurmaya çalıştılar. Bu durum Moğol işgali öncesi, özellikle Alâeddin Keykûbad'ın ölümünden sonra güçlenen vezirler için büyük fırsatlar doğurdu. ${ }^{49}$ Kimlerin vezir yapılacağına veya hangi vezirin görevini devam ettireceğine ilhanlı merkezi karar veriyordu. Dolayısıyla bu kişiler fiilen İlhanlı Han'ın vezirleriydiler. ${ }^{50}$ Bu tarihten itibaren Selçuklu vezirler, bir yandan İlhanlı veziri gibi görev yaptılar, diğer yandan da kendi kişisel servetlerini ve güçlerini arttırmak için çalıştılar. Tıpkı İran'da olduğu gibi, makam elde etmek ve makamlarını korumak için Moğol aristokrasisi ile iyi ilişkiler kurmak zorunda idiler. 1246 yılında Selçuklu Sultanı Keyhüsrev'in ölümü ile birlikte, Selçuklu topraklarının farklı bölgelerinin yönetimi verilen küçük yaştaki oğulları farklı çıkar gruplarının etkisi altında kaldılar. Bu durum vezirlerin ve bürokratların etkilerinin daha da artmasına neden oldu.

Bu dönemde Illhanlılar ile ortaya çıkan yeni düzeni en iyi kullanan ve en çok güçlenen bürokrat şüphesiz vezir Müineddîn Pervâne olmuştur. Aksarayî’ye göre tam teçhizatlı dört bin süvari ile birlikte Sinop'u ele geçiren vezir Müineddîn Pervâne Danişmendiye valisi unvanı almış ve güç ve itibarını iyice arttırmıştır. Başta Moğol tümen emiri Nabşi Noyan olmak üzere Rükneddin Kılıç Arslan'a muhalif olan emirler ile işbirliği yapmıştır. Bu konu ile ilgili Aksarayî şu olayı nakletmektedir:

Tüm bunlardan cesaret alan Pervâne bir gün Sultan'ın yüzüne karşı korkusuzca sert sözler söyleyince Sultan incinir. Pervâne'ye "Ağabey (ici) sarhoş musun veya uyuşturucu (haşiş) mu aldın?"

\footnotetext{
${ }^{47}$ Yinanç, a.g.e., s.149.

${ }^{48}$ Turan, a.g.e., s.29, 107.

49 Hatta Melville Selçuklu yönetiminin varlığını sürdürmesi Vezir Mühezzibeddin Moğollar ile yaptığı müzakereler sonucu olduğunu ileri sürmektedir. Melville, a.g.m., s.54, 62 .

${ }^{50}$ Melville, a.g.m., s. 56.
}

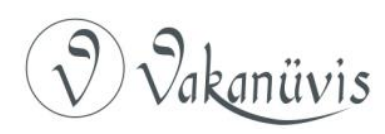


diye sordu. Pervâne "evet! Beni senin uygunsuz davranışın sarhoş edip uyuşturdu. Seni Burdur kalesinden ben çıkarttım. Senin saltanatının düzeni, benim tedbirimle yoluna girdi. Ilahi takdir sebebi ile benim hizmetimin hakkını tam olarak tanımadın." ${ }^{51}$

Sultan Rükneddin Kılıç Arslan Nabşi Noyan'ın düzenlediği bir ziyafette zehirlenerek öldürüldü. Pervâne ve Nabşı Noyan onun yerine altı yaşındaki oğlu Sultan Gıyaseddin Keyhüsrev'i tahta çıkardılar $(1265-66) .^{52}$

Müineddîn Pervâne sadece Selçuklu Devleti'ne değil, İlhanlı hanedanlığına da sadık kalmamıştır.Hapse atılan Karaman Türkmenlerini gizlice hapisten çıkarmış, elde ettiği gelirleri merkeze yollamamak için vakıflar kurmuş ve paraları burada biriktirerek kendisini ve ailesini zengin etmiştir. Bir hükümdar gibi yaşamış, pek çok eser inşa ettirmiştir. ${ }^{53}$ illhanlı'nın en büyük rakibi Memluklu Sultanı Baybars'a gizli destek vermiş, illhanlı'nın Memluklu ile yapılan savaşta yenilmesi üzerine onun bu desteği anlaşılmış ve 1277 yılında idam edilmiştir. ${ }^{54}$ Tüm bunlar, Pervâne'nin bir devlet memurundan çok, kendisi ve maiyeti için mücadele eden bir emir gibi davrandığını göstermektedir.

Pervâne'den sonra yerine geçen Vezîr Sâhip Fahreddîn Ali, çok büyük siyasi ve ekonomik güce sahip olmasına rağmen diğer bürokratlardan daha farklı hareket etmiştir. Hem Moğollar ile iyi geçinmeye çalışmış, hem de Selçuklu sultanlarına daha saygılı davranmıştır. Halk tarafından da çok sevilen Fahreddîn Ali'ye "ata" lakabı verilmiştir. ${ }^{55}$ Ancak o, kötüye giden siyasi ve idari gelişmelerle mücadele ederken, kaynaklara göre üzüntüsünden 1288 yılında vefatı

\footnotetext{
${ }^{51}$ Aksarayî, a.g.e., s. 84-85; Öztürk, a.g.e., s.64-65.

${ }^{52}$ Aksarayî, a.g.e., s. 87; Öztürk, a.g.e., s.66.

${ }^{53} \mathrm{Bu}$ konuda ayrıntılı bilgi için bkz. Togan, İsenbike, "variation in the Perception of Jasagh", History of Central Asia in Modern Medieval Studies (In Memoriam of Professor Roziya Mukminova), Taşkent, 2013, s. 88-96

${ }^{54}$ Aksarayî, a.g.e., s. 116; Öztürk, a.g.e., s.89;Turan, a.g.e., s.149-150.

${ }^{55}$ Merçil'e göre Vezîr Sâhip Fahreddîn Ali yaklaşık kırk yıl süren devlet hizmeti sırasında Moğollar ile başa çıkılamayacağını anladığı için onlarla iyi geçinmeye çalışmış, idare ve divan işlerinde isabetli kararlarıyla tanınmıştır. Erdogan Merçil, TDV Ansiklopedisi, Cilt: 35, s 516; Ayrıca bkz. El-Ömeri, Türkler hakkında Gördüklerim ve Duyduklarım (Mesâlikü'l-Ebsâr), Çeviri ve Notlar: D. Ahsen Batur, İstanbul, 2014, s.141.
}

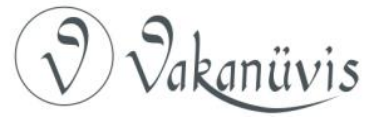


etmiştir. ${ }^{56}$ Yerine 1283 'te Fahreddîn Kazvinî Türkiye Selçuklu vezirliğine tayin edilmiştir. ${ }^{57}$ Bu tarihten itibaren Türkiye Selçuklu vezirleri kendi bünyesinde yetişmiş devlet ricalinden değil de illhanlı Devleti bünyesinden doğrudan tayin edildiler. ${ }^{58}$ Aksarayî onunla ilgili olarak şunları söylemektedir: “O, Anadolu'ya gelirken yanında Tebrizli, Hemedanlı, Iraklı, İsfahanlı, Horasanlı, Gürcü, Alanlı ve Tiflisli kimselerden çok sayıda toplulukla geldi. Bunların bazılarını hacibliğe bazılarını naibliğe getirdi. Ülkenin istifâ (mansıb-ı istifâ memâlik) makamını kardeşi Cemâleddîn'e ve pervaneliği diğer kardeşinin adına ayırdı. Kazvinî ile birlikte Rum emirliğine atanan Emir Şah Kazvinî ile işbirliği içinde hareket etti." ${ }^{59}$ Ayrıca yazar, onun vergileri çok arttırdığını, halka karşı çok büyük baskı ve zulümler yaptığını ayrıntılı bir şekilde ifade etmektedir. ${ }^{60}$ Daha sonra Ahmed Laguşi ve Alâeddin Sâvî, Illhanlı Devleti menşuru ile Türkiye Selçuklu vezirliğine doğrudan tayin edildiler, ${ }^{61}$ ancak idari ve siyasi istikrarsızlık ve halka yapılan zulüm ve baskılar devam etti. ${ }^{62}$

İlhanlı'nın Selçuklu üzerinde doğrudan siyasi hâkimiyet kurmak yerine, iç çatışmalardan ve Selçuklu devlet sisteminin zayıf noktalarından akıllıca istifade ederek hâkimiyet kurma politikası başarılı olmadı çünkü Melville'in de belirttiği gibi, Selçuklu sultanları değil de, büyük önem kazanan ve sayıları artan bürokratların bitmek bilmeyen hırs ve rekabetleri, kişisel çıkarları peşinde koşmaları

\footnotetext{
56 Yinanç, a.g.e., s. 276, 296-308; Anonim Selçuknâme'de Sâhib Fahreddin'in "Moğolların elinden çaresiz kaldığını, fazla düşünmekten ve kederden ishâle" yakalandığını ve bu hastalığından kurtulamayarak 2 Kasım 1288'de öldüğünü yazmaktadır. Anonim Selçuknâme, s. 56. Benzer bir şekilde Aksarayî'de onun o dönemde halka zulmeden, ağır vergiler getiren Sâhib Kazvinî'ye karşı koymak için "keskin kılıcını nişanına doğrultmuş, tamah dişini bilemiş vaziyette" iken eceli ile öldüğünü ifade etmekte ve "Kendisine zarar veren kimsenin kime faydası olur?" dizeleri ile de onun ölümünde, yaşadığı sıkıntıların rolü olduğunu ima etmektedir. Aksarayî, a.g.e., s. 150; Öztürk, a.g.e., s.118.

57 Aksarayî́ye göre Fahreddîn Ali daha hayatta iken Fahreddîn Kazvinî’ye " sâhip" unvanı verilmişti ve ona "nizâmü’l-mülk" lakabı ile hitap ediyorlardı. Aksarayî, a.g.e., s. 149; Öztürk, a.g.e., s.117.

${ }^{58}$ Turan, a.g.e., s. 44.

${ }^{59}$ Aksarayî, a.g.e., s. 148-149; Öztürk, a.g.e., s.117-118.

${ }^{60}$ Aksarayî, a.g.e., s. 152; Öztürk, a.g.e., s.120-121.

${ }^{61}$ Turan, a.g.e., s.44.

${ }^{62}$ Aksarayî, a.g.e., s.189-300; Öztürk, a.g.e., s. 152-239; Turan, a.g.e., s.101.
}

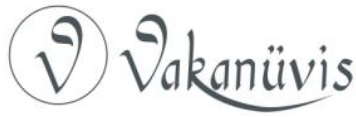


karmaşa ve kaosu artırdı. ${ }^{63}$ Anadolu'da adeta "vezirler saltanatı" yaşandı. İlhanlı hâkimiyeti sırasında Anadolu'da dini ve sivil mimari eserlerin hemen hepsinin vezirler tarafından inşa ettirilmesi ${ }^{64}$ de bunun kanıtı gibidir. Anadolu'da vezirler merkezin denetiminden uzak ve İlhanlı çıkarlarının temsilcileri olarak daha özgürce hareket edebilmeleri, bir yandan makam ve mevki satın alabilmek ve gücünü koruyabilmek diğer yandan illhanlı hanlarına vaat ettikleri vergileri yollayabilmek beraberinde Anadolu halkına karşı büyük adaletsizliklerin yapılmasına ve siyasi ve sosyal karmaşaların artarak devam etmesine sebep oldu. Birbirlerini denetlemesi için görevlendirilen Noyanlar ve emirler işbirliği yaparak hizipleşmeler içinde yer aldılar ve bu iki zümre efendilerine vergi veren halka çoğunluklu baskıcı oldular. ${ }^{65} \mathrm{Hem}$ İran hem de Anadolu örneklerinde olduğu gibi ehl-i kalem sınıfı tıpkı ehl-i kılıç sınıfı gibi kişisel servetlerini ve devlet sisteminde aile bireyleri ve akrabaları ile birlikte güçlendirip kadrolaşmaya çalıştılar. Bundan dolayı, maaşları dışında meçhul kaynaklardan elde ettikleri büyük bir servete sahip oldular. ${ }^{66}$

Ayrıca Anadolu'da merkezi otoritenin zayıflığı sadece emirleri değil aynı zamanda ehl-i kalem sınıfını da kendi müstakil devletini kurma hayalleri kurmalarına sebep oldu. Örneğin, Selçuklu veziri Saadeddin Köpek, çok güçlenince "Beylerbeyi" (Emîrü'l-Ümerâ/Melikü'l-Ümerâ) sıfatıyla Türkiye Selçuklu ordusunun başına geçti, hatta Selçuklu tahtına oturma planları bile yaptı. ${ }^{67}$ Vezir Fahreddin Ali'nin oğulları Karahisar'da hüküm sürmüşler, burada bir beylik olarak burada yaşamışlardır. Sonradan Germiyanlılar'a tâbi olmalarına rağmen bu bölge "Karahisar-i Sâhib" veya "Karahisar-ı Devle" adını muhafaza etmiştir. Pervâne oğulları Beyliği Sinop ve Kastamonu'da Pervâne Muinüddin Süleyman'ın oğulları tarafından kurulmuştur. Muhtemelen 1324'te Aksarâyî Candarin Oğlu Süleyman Paşa'nın Kastamonu ve Sinop'u ele geçirmesiyle sona ermiştir. Kadı Burhâneddin Ahmed Devleti (1381-1389), Kadı Burhâneddin Ahmed tarafından Selçuklular'ın halefi Eretna Devleti'nden sonra Orta Anadolu'da

\footnotetext{
${ }^{63}$ Melville, a.g.m., s.80.

${ }^{64}$ Melville, a.g.m., s.2009, s. 65.

${ }^{65}$ Melville, a.g.m., s. 99.

${ }^{66}$ Danuu, a.g.e., s. 349.

${ }^{67}$ Koca, a.g.m., s. 86-87.
} 
kurulmuş bir devlettir. Kadı Burhâneddin, kadılık, vezîrlik ve nâiblikten hükümdarlığa yükselmiş bir şahsiyettir ve Türk menşelidir. ${ }^{68}$

Yukarıdaki örneklerde görüldüğü gibi, ehl-i seyf sınıfı gibi merkezi otoritenin karşısında yer alarak kendi siyasi ve ekonomik çıkarları için mücadele eden ehl-i kalem sınıfının bu faaliyetleri neden tarihi kaynaklarda ehl-i seyf sınıfının yaptıklarının gölgesinde bırakılmıştır? Neden isyan, itaatsizlik muhaliflik daha çok ehl-i seyf ile özdeşleştirilmiştir? Hâlbuki Gazan Han'ın merkezi otoriteyi tesis etmek için yaptığı reformlardan her iki zümre de hoşnut olmamış ve emirler gibi vezirler de bu reformların başarısız olmasında etkili olmuşlardır. ${ }^{69}$

Bunun altında yatan en önemli sebep, tarihteki ehl-i kalem ve ehl-i seyf sınıfı arasındaki ilişkiyi ehl-i kalem sınıfının yazdıkları aracılığı ile

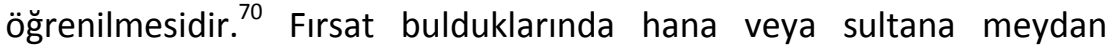
okuyan, her fırsatta isyan eden emir/bey figürü bütün tarih yazımında hâkim görüş olmuştur. Hatta Türk ve Moğol hükümdarlar genellikle devlet yönetimini bu işten daha iyi anlayan vezirlere verdiklerini, kendilerinin daha çok savaşmakla uğraştıkları fikri genel bir kanı olarak tarih yazımında işlene geldi. Barfield'ın ifade ettiği gibi, zor anlayan (slow-witted) Türkçe konuşan Şah ile çokbilmiş kurnaz (crafty) İranlı vezir Sa'di'nin şiirlerinin ana karakterleri olmuşlardır. ${ }^{71}$ Zeki Velidi Togan'da Reşîdüddîn, Vassâf, Hamdullah Müstevfî, ỉbn Bibi, Kerimeddin Aksarayî gibi ehl-i kalem'in yazdıkları eserlerinde kendi rol ve önemlerini çok abartmaları sonucu, vezir hükümdar idealizminin veya vezir ve bürokratların hükümdarın hizmetinde devletin düzeni ve istikrarı için çabaladıkları düşüncesinin bu denli yaygınlık kazandığını ileri sürmektedir. ${ }^{72}$

Bu vezirler, eserlerinde hep ideal olanı yazmışlar ama uygulamada farklı davranmışlardır. Petrushevsky'e göre en önemli vergi kaynağı

\footnotetext{
${ }^{68}$ Turan, a.g.e., s.152-153.

69 Özgüdenli, a.g.e., s.291.

${ }^{70}$ Manz, a.g.m., s. 335-336.

${ }^{71}$ Barfield, a.g.m., s. 172. Bu konuda Manz, Türk ve Moğol liderlerin Orta Doğu'nun tarım alanlarının, şehirlerinin kendileri için gerekli olan gelirleri barındırdığının farkında olduklarını ve bu kaynaklardan faydalanabilecekleri politikalar geliştirmeye çalıştıklarını belirtmektedirler. Manz, a.g.m., s.337-348

72 Z.V. Togan, a.g.e., s. 248-249.
}

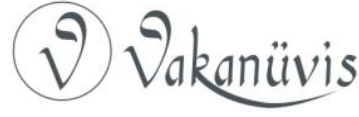


olan köylünün üzerindeki vergi yükünün azaltılması, yaşam seviyelerinin yükseltilmesi ve sivil ve mali bürokrasinin etkili çalışacağı bir ortamın oluşturulması fikirlerini savunan Reşîdüddîn'in, Nizâmü'l Mülk ve Gazali'den farklı bir şey söylememiştir. O, Ülkenin istikrarını köylüyü korumaya bağlamıştır. Ona göre en önemli vergi ödeyicileri olarak köylünün hayatını kolaylaştırmak, tarımı restore etmek ve vergileri arttırmak ve köylüleri isyan etmekten alıkoymak için gereklidir. ${ }^{73}$ Ayrıca Reşîuüddîn, Mukatabat adlı eserinde ise açık bir şekilde Türk ve Moğolların zalim olduklarını ve köylüye baskı uyguladıklarını ifade etmektedir. ${ }^{74}$ Manz ise ilhanlı topraklarında köylülerin baskı görmesinin sebebinin yeri geldiğinde ağır vergi yükü altında ezilen göçebeler olmadığını, yerleşik ekonomi üzerinde hakları olduğunu iddia eden hanedanlığa bağlı önemli emirler ve kazanmaya hevesli İranlı memurlar olduğunu ileri sürmektedir. Sıradan göçebeler ile sıradan köylülerin haksız uygulamalardan eşit derecede etkilendiklerini ileri sürmektedir. ${ }^{75}$ Hatta Çağatay Türk Edebiyatının önemli şahsiyetlerinden ve bir Timurlu bürokratı olan Ali Şir Nevai, vezir kelimesinin "vizr"den türetildiğini, günah suç anlamına gelen bir fiilin vezirlere yakışan bir fiil olduğunu düşünmektedir. Nevai'ye göre vezirler halkın biriktirdiği malı toplarlar, padişahın tahtı ve memleketi bu zalimlerin elinde berbat olur. Onları zehir verip hastayı öldüren doktorlara benzetmektedir. ${ }^{76}$ Reşîuüddîn'in yukarıda bahsedilen o muazzam serveti muhtemelen adil bir vergi sistemi ile oluşturulmamıştır. Petrushevsky'e göre ehl-i kılıç zümresi emirler merkezkaç eğiliminde olan ve merkezi otoriteye itaat etmeyen insanlar, ehl-i kalem ise eski İran devlet geleneğinin güçlü feodal devlet ve güçlü merkeziyetçi politikasını benimsemişlerdir. ${ }^{77}$ Aslında her iki zümre farklı gibi görünseler de, onlar hükümdarla gücü paylaşmayı salık veren bir siyasi anlayışa sahip oldukları anlaşılmaktadır.

\footnotetext{
${ }^{73}$ Petrushevsky, a.g.m., s.151-154.

${ }^{74}$ Petrushevsky, a.g.m., s. 148-162.

${ }^{75}$ Manz, a.g.m., s.348-351.

76 A. B. Ercilasun,"Ali Şir Nevai'nin Mahbubü'l-Kulub'ünde Devlet Anlayışı," 16. Milletlerarası Altaistik Kongresi 21-26 Ekim 1973 Ankara Bildrleri, Ankara 1979, s.108, Hayrunnisa Alan Akbıyık 'ın "Timurlularda Vezîrlik Müessesesi", TTK Bildiriler, XIV (2005), I, 97-106 adlı çalışmasından alınmıştır.

77 Petrushevsky, a.g.m., s.154-156.
}

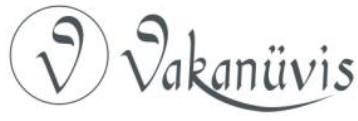


Ehl-i kalem sınıfının ehl-i seyf sınıfına karşı olumsuz söylemler kullanmaları sadece onlar ile aralarında olan siyasi rekabet yüzünden değil aynı zamanda kendi topraklarını ele geçiren göçebelere karşı doğal olarak besledikleri olumsuz duygulardan kaynaklandığı söylenebilir. Manz bu konuda "fethedenlerin tarihini fethedilenler yazmıştır ve onlardan tarafsız olmalarını beklemek gerçekçi bir yaklaşım olmasa gerekir" demektedir. ${ }^{78}$ Yerleşiklerin tarihini Ali Şir Nevai gibi Türk kökenli yazarlar yazsa idi belki bugün sadece Türk ve Moğolların değil, yerleşiklerin de tarihini farklı yazılabilirdi. Ayrıca bu yerleşik göçebe ikilemi sadece fetheden ve edilen arasında olmamış, zaman içinde şehirlere yerleşerek devlet yönetiminde görev alan veya şehir hayatına geçen göçebeler ile geleneksel göçebe yaşam tarzını sürdüren kuzenleri arasında da yerleşik-göçebe çatışması yaşanmıştır.

\section{Sonuç}

İlhanlılar'ın adem-i merkezi yapıyı değiştirmeden, Türk-Moğol aristokrasisinin karşısına yerli bürokrasiyi koyarak bir kontrol-denge mekanizması kurmaya çalışmışsa da adem-i merkezi yapının sağladığı uygun siyasi ve idari yapılanma her iki zümrenin bazen dost bazen düşman olarak kendi çıkarları doğrultusunda hareket etmesine ve ülkenin siyasal, sosyal ve ekonomik sorunların pençesinde kalmasına sebep oldu. Bu olumsuzluklar Anadolu'da daha şiddetli yaşanmıştır çünkü Anadolu'nun merkezin kontrolünden uzak olması, vezirlerin İlhanlının temsilcisi olarak görev yapmaları onların çok daha fazla yetki ve güce sahip olmasının önünü açmıştır. Şehirlerde toplanan, Farsça konuşan ve dış dünyaya kapalı kendi sosyo-kültürel çevresinde yaşayan, yönettiği, vergi aldığı insanlarla hiçbir rabıtası olmayan bu ehli kalem sınıfı, denetleme mekanizmasının zayıflığından da istifade ederek, Anadolu'da çok büyük sosyal, siyasal ve ekonomik sorunlara yol açtılar. Anadolu halkı, yıllarca bu olumsuz gelişmelerden o kadar çok zarar gördü ki, Anadolu'ya vali olarak atanan bir Moğol valisinin ülkede siyasi, sosyal ve ekonomik istikrarı sağlaması üzerine, onun

${ }^{78}$ Manz, a.g.m., s.335-336, 564. Ayrıca bu konuda ayrıntılı bilgi için bkz. Christopher Beckwith, ipek Yolu Imparatorlukları;Bronz Çağı'ndan Günümüze Orta Asya Tarihi, Ankara, 2011, s.1-16.

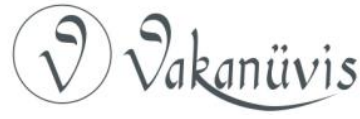


mehdi olduğuna inandı. ${ }^{79}$ Kısaca ilhanlı vezirleri örneklerinde gösterilmeye çalışıldığı gibi ehl-i seyf ve ehl-i kalem sınıfının görev ve sorumlulukları, sosyo-kültürel alt yapıları farklılıklar göstermekle birlikte, her iki zümre kendi çıkarlarını devletin çıkarlarından üstün tutmuşlardır. Veya var olan sistemde başka türlü var olmak mümkün olmadığı için o şekilde hareket etmek zorunda kalmışlardır. Ancak tarihi kaynaklar ve o kaynaklara dayanarak çalışma yapan yazarlar genel olarak ehl-i kalem sınıfını Türk-Moğol devletlerinde yaşanan siyasi, sosyal ve ekonomik sorunların en büyük sorumlusu olarak göstermişlerdir.

\section{Kaynakça}

Aigle, Denis, "Iran under the Mongol Domination: The Effectiveness and failings of a Dual Administrative System", Le Pouvoir À lâge Dessultanats Dans Le "Bilād al-Shām/Power in the Age of Sultanates in the "Bilād al-Shām" Institut Francais du Proche-Orient 2006-2007, s. 65-78.

Aksaraylı Mehmed Oğlu Keriüddin Mahmud, Müsâmeret ül-Ahbâr; Moğollar Zamanında Türkiye Selçukluları Tarihi, Mukaddime ve Haşiyelerle Tashih ve Neşreden Osman Turan, Ankara 1944.

Mahmûd bin Muhammed Aksarayî, Müsâmeretü'l-Ahbâr ve Müsâyeretü'l Ahyâr, Çev. Mürsel Öztürk, Ankara 2000.

Anonim, Tarîh-i Âl-i Selçuk; Anonim Selçuknâme, Tercüme ve Notlar, Halil ibrahim Gök, Fahreddin Coşguner, Ankara 2014.

Barfield, Thomas J., "Tribe and State Relations: Inner Asian perspective," Tribes and State Formation in the Middle East Ed. Philip S. Khoury and Joseph Kostiner, Univ. of California Press, 1990, s.153-182.

Beckwith, Christopher, ipek Yolu imparatorlukları;Bronz Çağı'ndan Günümüze Orta Asya Tarihi, Ankara 2011.

Dalkesen, Nilgün, "ilhanlı Valisi Emir Timurtaş'ın isyanı," Kebikeç,.43 ( 2017), s.301-324.

Danuu, Ankhbayar, IIhanlı Devleti'nde Vezaret, Yayınlanmamış Doktora Tezi, Ankara 2016.

Erdem, Illhan, “Olcaytu Han'ın Ölümüne kadar IIlhanlılar'da Yaşanan Siyasal-Kültürel Gelişmeler ve Yakın-Doğu'ya Etkileri", (ayrı basım), AÜDTCFTAD, 31 (2000), s.1-35.

${ }^{79}$ Bu konuda ayrıntılı bilgi için bkz. Nilgün Dalkesen, İlhanlı Valisi Emir Timurtaş'ın isyanı," Kebikeç, 43(2017), s.301-324.

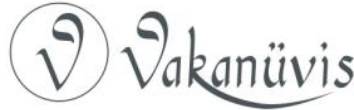


Hunkan, Ömer Soner, Türk hakanlığı (Karahanlılar) (3. Baskı), İstanbul 2011.

Levi, Scott C. \& Sela, Ron (ed.), Islamic Central Asia: An Anthology of Historical Sources, Bloomington, 2010.

el-Kâşânî, Âbû'I-Kâsim Abdullah bin Muhammed el-Kâşânî, Târîh-i Olcâytû, Tahran 1348.

Koca, Salim, "Sultan Alâeddîn Keykubâd'dan Sonra Türkiye Selçuklu Devleti Idaresinde Ortaya Çıkan Otorite Z ôfiyeti ve Emîr Sadeddîn Köpek'in Selçuklu Saltanatını Ele Geçirme Teşebbüsü," Gazi Üniversitesi Türkiyat Araştırmaları Dergisi, 7 (Güz 2010), s.65-97.

Manz, Beatrice Forbes "Reflections on Nomads, Agriculture and Urban Life", Horizons of the World: Festschrift for İsenbike Togan (Hudûdü'l-Âlem: İsenbike Togan'a Armağan), ed. İlker Evrim Binbaş\&Nurten Kılıç-Schubel, İstanbul 2011, s. 325-357.

Melville, Charles, "Abû Saî'd and the Revolt of the Amirs in 1319", L'Iran Face $\dot{A}$ La Domination Mongole, Ed. By

Melville, Charles, "Anatolia under the Mongols", The Cambridge History of Turkey, Vol I, Byzantium to Turkey 1071-1453, Yay. Kate Fleet, Cambridge University Press 2009, s. 51-101.

Petrushevsky I. P., "Rashīd al-Dīn's Conception of State", Central Asiatic Journal, $14,1 / 3$ (1970), s. 148-162.

El-Ömeri, Türkler hakkında Gördüklerim ve Duyduklarım (Mesâlikü'lEbsâr), Çeviri ve Notlar: D. Ahsen Batur, İstanbul 2014.

Özgüdenli, Osman Gazi, Gâzân Han ve Reformları, İstanbul 2009.

Rashîd el-Dîn Fazlullâh, Câmi'el-Tevârîh, ed. Behmen Kerîmî, Tahran 1387, Spuler, Bertold, Iran Moğolları; Siyaset, Idare ve Kültür, ihanlılar Devri, 12201350, Çev. Cemal Kprülü, Ankara

Sümer, Faruk, "Anadolu'da Moğollar", Selçuklu Araştırmaları Dergisi I, 1969, Ankara 1970, s.1-145.

Togan, Zeki Velidi, Umumi Türk Tarihine Giriş, İstanbul 1970.

Togan, İsenbike, "variation in the Perception of Jasagh", History of Central Asia in Modern Medieval Studies (In Memoriam of Professor Roziya Mukminova), Taşkent 2013, s. 67-100.

Turan Refik, Türkiye Selçuklularında Hükümet Mekanizması (Vezîr ve Divân), İstanbul 1995.

Yinanç, Mükremin Halil, Türkiye Tarihi Selçuklular Devri, II. Cilt, Yayına Hazırlayan Refet Yinanç, Ankara 2014.

Yusuf Has Hacip, Kutadgu Bilig, Haz. Yaşar Çağbayır, (8. Baskı), Ankara 2011.

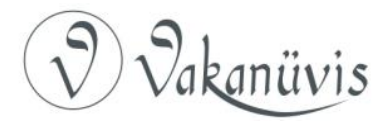

